\title{
Mobile Platform Biometric Cloud Authentication
}

\author{
Agostinho Marques Ximenes $^{1, \text { a }}$, Sritrusta Sukaridhoto ${ }^{2 . b}$, Amang Sudarsono ${ }^{3 .}$, Hasan Basri $^{4 . d}$ \\ ${ }^{1}$ Dept. Informatics Engineering, Insitituto Superior Cristal, Doad Balide, Dili, Timor Leste \\ ${ }^{2,3}$ Program Studi Teknik Informatika dan Komputer, Politeknik Elektronika Negeri Surabaya, \\ Jl. Raya ITS, Surabaya, Jawa Timur, Indonesia \\ ${ }^{4}$ Program Studi Manajemen Informatika, Politeknik Negeri Fakfak, \\ Jl. Imam Bonjol Atas, Air-Merah, Wagom, Fakfak, Papua Barat, Indonesia \\ agusmarques1@gmail.com, \\ bdhoto@pens.ac.id \\ camang@pens.ac.id \\ hasan@polinef.id
}

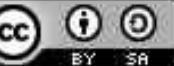

Abstract-Based on the Indonesian Central of Statistics the level of poverty people in September 2018 was 25.95 million, based on data, the government allocation care funds the reduce poverty people, the fund is given through the bank. However, the bank cannot allocation funds because the cost for build infrastructure is expensive, such as making an ATM. about that, the banks need to find a new solution to allocation care fund to the poverty people. In this paper, a mobile platform biometric cloud authentication is one of platform used for the online payment transaction at merchants. The implementation of the biometric face recognized (face data encrypt and decrypt used algorithm AES 256 bit) and QR Code to secure online payment merchant base on mobile cloud authentication, that play role in data communications security. The test results on this mobile application show that scanning a $Q R$ Code and biometric face recognized can be implemented at an online merchant transaction with an accuracy of $95 \%$ and takes 53,21 seconds in transactions.

Keywords-Biometrics; Cloud; Cryptography; QR Code.

Abstrak-Berdasarkan data Pusat Statistik Indonesia, tingkat kemiskinan pada bulan September 2018 adalah 25,95 juta, berdasrkan data tingkat kemiskinan masyarakat tersebut pemeritnah menyalurkan dana bantuan mengatasi tingkat kemiskinan masyarakat melalui Bank. Namun, Bank tidak dapat mengalokasikan dana karena biaya untuk membangun infrastruktur mahal, seperti membuat ATM.Berbagai kendala tersebut, Bank perlu menemukan solusi baru agar dapat mengalokasikan dana kepada masyrakat dengan biaya yang murah, Mobile Platform Biometric Cloud Authentication adalah salah satu solusi.Dalam penelitian ini, eksperimen yang dilakukan melakukan autentikasi dengan QR Code Scan dan face recognize (data face dienkripsi dan didekripsi dengan kritografi algoritma AES 256 bit). Konsentrasi penelitian ini terletak pada eksperimen terhadap komunikasi keamanan data transaksi payment merchant onlie degan QR Code scan dan Face recognize yang berbasis mobile android dan serta spesfikasi android versi 23. Hasil pengujian pada aplikasi Mobile ini menunjukkan bahwa $Q R$ Code scan dan face recognize dapat diimplementasikan pada transaksi payment merchantonline dengan akurasi $95 \%$ dan membutuhkan 53, 21 detik per transaksi.

Kata Kunci-Biometrik; Server Cloud; Kriptografi; QR Code.

\section{Pendahuluan}

Berdasarkan data Badan Pusat Statistika Indonesia tingkat kemiskinanmasyarakat pada bulan September tahun 2018 sebanyak 25.95 juta orang [1], berdasarkan data tersebut maka pemerintah melakukan penangulangn tingkat kemiskinan masyarkat dengan memberikan dana kesejaterahan kepada masyarkat miskin, bantuan tersebut disalurkan melalui Bank.Namum bank memiliki kendala untuk mencairkan dana karena biaya pembangunana infrastruktur dan administrasi yang mahal seperti pembuatan ATM.

Perkembangan teknologi dan ketergantungan manusia terhadap teknologi, dan serta teknologi sudah merambah ke berbagai bidang baik itu industri, manufaktur, pendidikan, pemerintah, bisnis, perbankan, dan serta kehidupan sehari-hari manusia[2]-[4].

Mobile sebagai salah satu pelayanan yang sangat berkembang saat ini, karena dengan mobile sangat membantu dan mempermudah bagi penguna bisa mengakses data dan informasi dimana saja tanpa dibatasi oleh media, ruang, waktu untuk mengaskes data dan informasi yang diingikan dan serta pengiriman data lebih cepat dan murah. Namun sisi keamanan sebagai salah satu kendala sering dihadapi baik berupa pencurian data, 
pencegatan data, kecurangan, dan pengaksesan data yang tidak sah [5], [6].

Sistem yang digunakan dalam keamanan saat ini terdiri dari sistem keamanan data dengan mengunakan teknik keamanan tradisional dengan kriptografi dan teknik keamanan modern dengan biometrik dan QR Code [7]. Kriptografi merupakan teknik penyamaran teks asli ke teks acak dengan mengunakan kunci, biomerik mengunakan karateristik manusia berupa sidik jari, retina, wajah, telapak tangan, DNA, dan telapak kaki untuk melakukan autentikasi [8].

Teknik keamanan data dan transaksi mengunakan teknik keamanan kriptgrafi dan biomerik masih memiliki kelemahan, dengan mengunakan teknik kriptografi memiliki kelemahan pencegatakan data, manipulasi data, perusakan data, dan serta penyebaran data kepihakm lain. Teknik keamanan moderndengan biomerik masih memiliki kelemahan atas pemalsuan karateristik biomerik.

Dari permasalahan tersebut yang akan dibahas sebagai berikut: (1) Memberikan solusi untuk mencairkan dana masyakarak dengan membangun aplikasi mobile transaksi, (2) Melakukan penyamaran data biometrik agar data biomerik tidak mudah dipalsukan. (3) Melakukan pengabungan sistem QR Code, biometrik(face) dan kriptografi(AES 256 bit) agar bisa menghasilkan tingkat autentikasi yang lebih kuat, handal dan aman, (4) Akurasi pada tingkat autentikasi biometrik untuk transaksi, dan (5) Mengukur berapa lama waktu yang dibutuhkan untuk melakukan transaksi.

Berbagai permasalahan yang telah di identifikasi maka peneliti mengajukan suatu pendekatan penyaluruan dana masyarakat kepada Bank dengan biaya pembangunan fasilitas yang murah, dan serta tingkat keamanan transaksi data yang aman, handal, dan kuat dengan membangun sebuah platform mobile dengan nama Mobile Platform Biometric Cloud Authentication.

\section{Metode Penelitian}

\section{A. Biometric Face Recognize}

Biometrik merupakan suatu teknik untuk mengindetifikasi seseorang dengan mengunakan karakteristik salah satu bagian dari tubuh manusia[9], [10]. Salah satu bagian tubuh manusia yang digunakan pada biometrik ini adalah face atau wajah. Teknik pengenalan seseorang mengunakan face recognizes atau pengenalan wajah pada saat ini banyak digunakan dalam sistem keamanan suatu perangkat. Salah satu sistem keamanan mengunakan face recognizes untuk mengunci dan membuka sebuah pinto atau perangkat mobile [5].

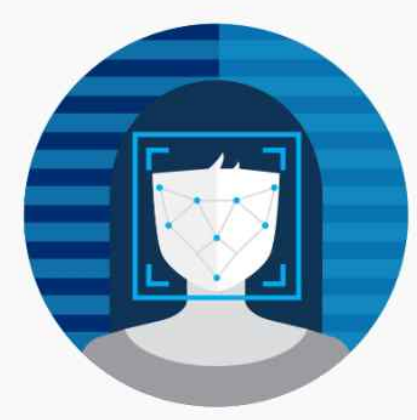

Gambar1. Biometric Face Recognize

Pada gambar 1 menjelaskan bahwa data wajah dari seseorang dapat disimpan dalam sebuah database dengan merubah data wajah menjadi sebuah karakter. Pengenalan pola posisi wajah dengan membuat persegi pada wajah untuk menentukan titik-titik pola wajah dan menentukan posisi wajah dengan mengambil nilai [9]. Autentikasi mengunakan pengenalan wajah atau face recognize terdapat 2 proses utama yaitu melakukan proses identifikasi wajah dengan melakukan penentuan posisi wajah, menentukan atribut yang diambil untuk melakukan training untuk mendeteksi wajah dan proses face recognize atau pengenalan wajah dengan melakukan pencocokan wajah antara data wajah yang telah di simpang di database dengan pengambilan potoh wajah baru [9], [10].

\section{B. Android Mobile APPS untuk Digital Payment}

Android Mobile apps atau aplikasi mobile android adalah aplikasi yang dibuat untuk smartphone,dapat diinstal dan dioperasikan di platform smartphone android. Android mobile apps berjalan pada java programming. Digital payment merupakan konsep transaksi yan berbasis digital. Jadi android mobile APPS for digital payment adalah sebuah aplikasi mobile android yang yang memanfaat fitur-fitur yang terdapat 
pada smartphome mobile untuk melakukan transaksi pembayarn, yang terdapat pada gambar 2 .

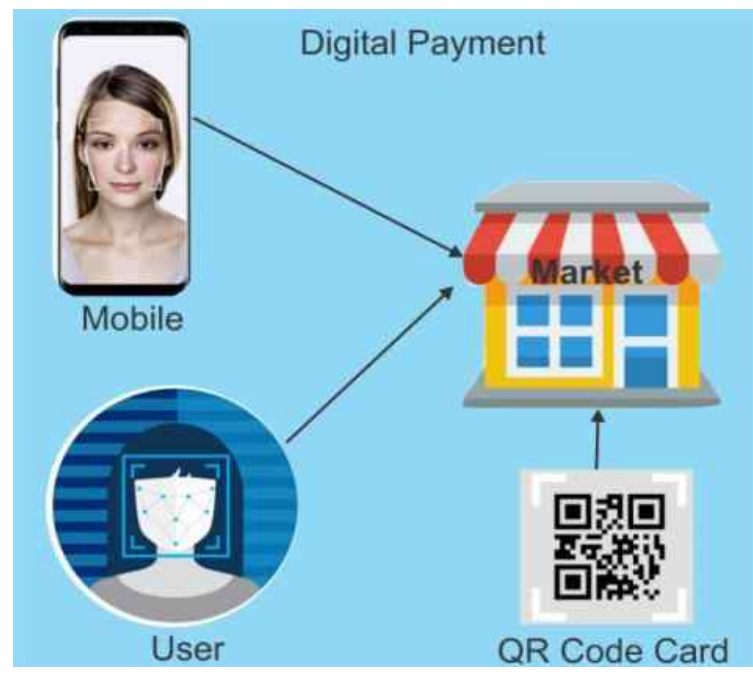

Gambar 2. Android Mobile APPS for digital payment

\section{a. QR Code}

QR Code (Quick Response Code) adalah dua dimensi yang dapat menyimpan data. QR code digunakan pertama kali di dunia otomotif untuk melakukan pelacakan bagian dari rangkaian kendaraan. Semakin berkembangnya pengunaan QR Code banyak di gunakan untuk menyebarkan alamat website. Nomor kontak, alamat email, nomor telepon, bahkan untuk pembayaran. Maka kehadiran sistem pembayara yang pada saat ini dan yang akan teknologi terus perkembang, mengunakan sistem pembayaran dengan salah satu sistem pembayaran teknologi QR Code (Quick Response Code) atau QR Paymnetsebagai solusi untuk mengatasi kebutuhan manusia atas keamanan data transaksi yang aman dan efesien [11]. ilustrasiQR Code pada gambar 3.

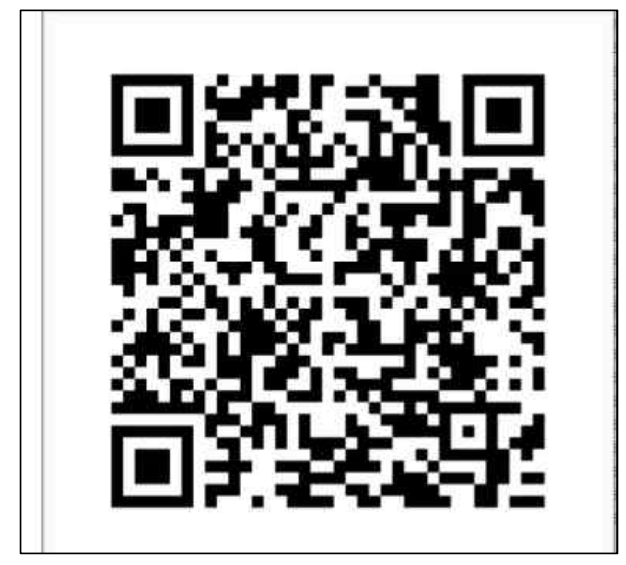

Gambar 3. QR Code

\section{b. Face API Azure}

Azure Face API adalah sebuah service algoritma cognitive untuk deteksi, pengenalan, dan menganalisa wajah manusia dalam gambar. Algoritma congnitive memiliki kemampuan untuk proses informasi yang ada wajah manusia, dan informasi tersebut bisa di implementasikan kedalam berbagasi sistem keamanan IU/UNIX pada mobile dan robot.Service cognitive Azure merupakan services kercerdasan buatan Microsoft berbasis cloud yang dapat digunakan pengembangan aplikasi berbasis artificial intelegent [9]. Pada Face API terdapat 2 proses, yaitu (1) face detection API untuk mendeteksi wajah manusia dalam gambar dan membuat koordinat lokasi persegi pada wajah. Setelah wajah dideksi ekstraksi fitur yang terkait dengan atribut wajah seperti pose, pose kepala, jenis kelamin, umur, emosi, rambut wajah, dan kacamata seperti pada gambar 4. (2) Face verification API untuk melakukan autentikasi dengan data wajah baru yang di ambil dengan kamera mobile dan melakukan deteksi wajah setelah wajah di deteksi maka data di lakukan pencocokan data wajah yang yang ada di database wajah. seperti pada gambar 5 . 


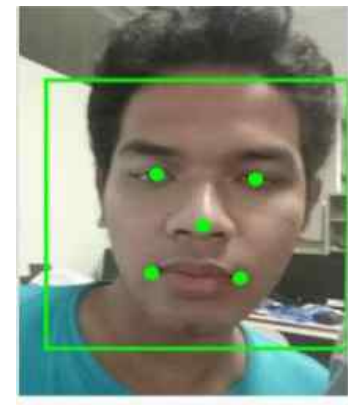

Gambar 4. Face Detect

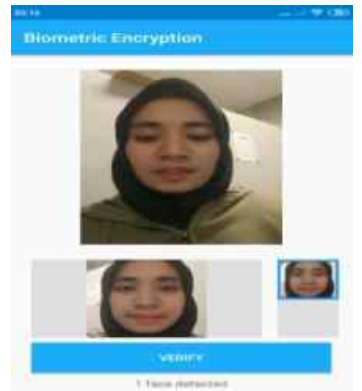

Gambar 5. Face verify
Pada gambar 4 merupakan proses deteksi wajah dan sebelah kanan gambar 5 sebagai proses verifikasi wajah

\section{c. Merchant}

Merchant adalah penjual barang atau jasa yang memiliki bentuk usaha (physical store) maupun online store yang bekerjasama dengan Bank dalam penyediaan layanan penerimaan pembayaran via e-money bank yang bersangkutan [7]. Merchant dibagi menjadi dua yaitu merchant perorangan dan merchant berbadan hukum. Merchant perorangan adalah merchant milik perorangan tanpa berdasarkan pada tata cara dan ketentuan pendirian usaha berbadan hukum. Sedangkan merchant berbadan hukum adalah merchant yang didirikan berdasarkan pada tata cara dan ketentuan pendirian usaha berbadan hukum yang berlaku. Setelah perorangan atau badan usaha mendaftar sebagai merchant, maka selanjutnya mereka akan memperoleh ID merchant .Ilustrasi merchant pada gambar 6 .

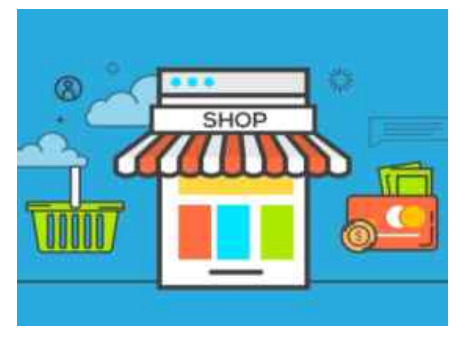

Gambar 6. Merchant Online

\section{d. Mobile Cloud Computing}

Mobile cloud computing merupakan salah satu infrastrurktur yang melakukan penyimpanan data dan proses yang dilakukan di luar dari pada perangkat mobile [12], [13], perangkat mobile memindahkan data komputasi dan melakukan penyimpanan data bukan langsung pada perangkat mobile melainkan penyimpanan data di cloud. Fitur yang sangat penting daripada platform mobile cloud terletak kolaborasi fungsionalitas antara platform mobile dengan cloud, dan melakukan akses melalui nirkabel yang berbasis pada web base atau client pada mobile platform [14]-[16].

\section{Metode penelitan}

Metode penelitiah yang dilakukan mengunakan metode penelitian kuantitatif dengan menganalisa tingkat akurasi verifikasi wajah dan QR Code dan waktu yang di perlukan untuk melakukan transaksi .

\section{Bahan penelitian}

Pada penelitian ini mengunakan beberapa software pendukung sebagai berikut:

\begin{tabular}{|l|l|l|}
\multicolumn{3}{c}{ Tabel 1: bahan penelitian } \\
\hline spec & Mobile & PC Server \\
\hline type & Samsung S8 & Cloud server \\
proc & Exynos 9 octa 8895 & Intel Xeon 4 Core Xeon \\
Ram & $6 \mathrm{~GB}$ & $16 \mathrm{~GB}$ \\
OS & Android & Linux Debian \\
Camera & $8 \mathrm{px}$ & - \\
Database & - & MongoDB \\
connect & $4 \mathrm{G}$ & $1 \mathrm{Gbs} / 100 \mathrm{Mbs}$ \\
\hline
\end{tabular}

\section{E. Prosedur pengujian}

Mobile Platform Biometric Cloud Authentication ada 2 bagian utama proses yaitu, (1) proses registrasi yang terdiri dari enrolment, store data to the cloud, dan create $Q R$ Code. (2) pada proses transaksi terdiri dari proses scan $Q R$ Code dan face verification, sotre transaction data, check balance, dan transaction permission.

\section{Hasil dan Pembahasan}

Pada tahap ini, melakukan pengujian terhadap implementasi dari desain system Mobile Platform Biometric Cloud Authentication(MPBCA) architecture yang memili 2 proses utama yaitu,(1) proses regisfrasi( enrolment, store data to cloud, create $Q R$ Code), dan (2) transaksi(scan $Q R$ Code + Face recognize, store data to cloud market, check balance, dan transaction permission). 


\section{A. Arsitektur Mobile Platform}

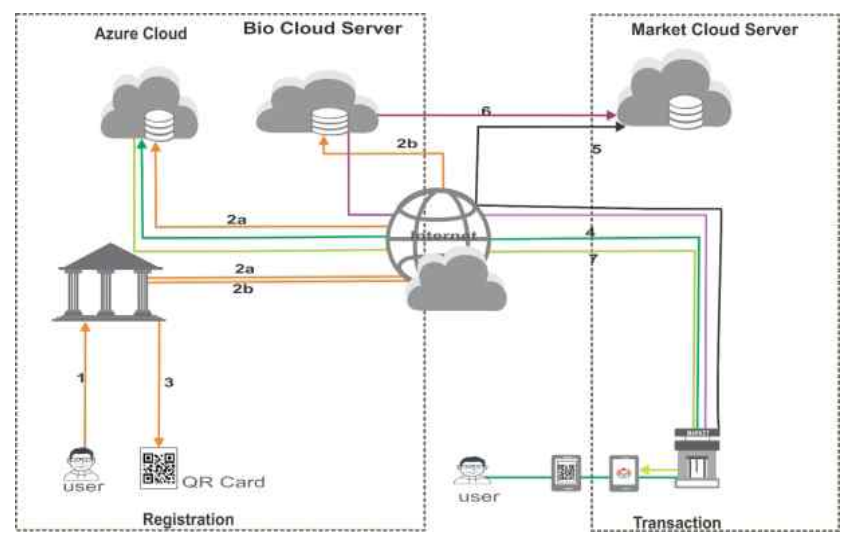

Gambar 7.Arsitektur Mobile Platform

Desain sistem arsitekrur Mobile Platform terdapat 2 proses utama yaitu;

a. Tahap Registrasi

1. Enrolment, pada tahap pendaftran melakukan pengisian nama, kunci, alamt tempat tinggal, nomor infuk penduduk (KTP), tempat tanggal lahir, jenis kelamin, saldo, pengambilan potoh biomerik wajah.

2. store data, menyimpan data wajah yang telah dienkripsi disimpang ke database cloud server yang dibuat oleh penelitih.

3. Create $C Q$ Code, sebagai kartu QR Code berupah logi ke aplikasi.

\section{b. Tahap Transaksi}

1.Scan $Q R$ Code and Face recognize, tahap ini melakukan scan kartu QR code penguna dan melakukan pengenalan wajah.

2.Store transaction data, tahap melakukan penyimpanan data transaksi di cloud server market.

3. Check balance, pada tahap ini melakukan pengecekan saldo terhadap junlah bayaran yang akan di bayar.

4.Transaction permission, melakukan proses transaksi setelah melakukan cek balance saldo, jika saldo cukup maka proses transaksi berhasil, jika tidak maka proses transaksi gagal.
Pada proses registrasi dan transaksi pada aplikasi tersebut dipaparkan dalam arstiketerur mobile platform biomerik authentication pada gambar 6 .

\section{B. Pada proses menu registrasi terdapat 3 proses utama yaitu:}

\section{a. Proses ujicoba Menu Enrolment}

Proses menu enrolment merupakan tahap registrasi yang terdiri dari 4 proses yaitu, (1) input user-id, (2) megambil gambar wajah, (3) deteksi wajah, dan (4) proses untuk simpan ke database. Ilustrasi terdapat pada gambar 8 .

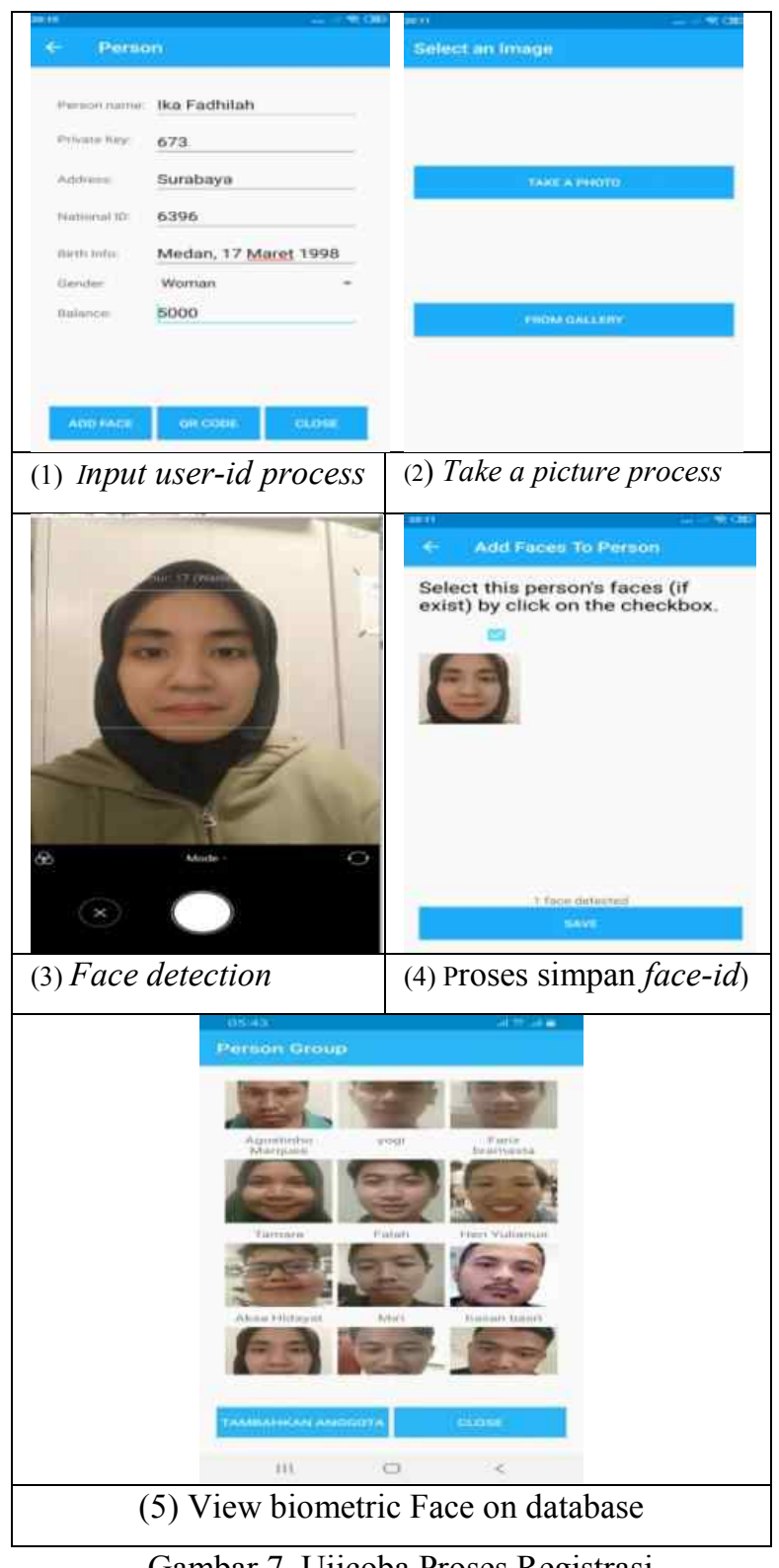

Gambar 7. Ujicoba Proses Registrasi 
Pada proses enrolment gambar 7, bagian nomor (1) menu proses user-id terdapat beberapa atribut yang digunakan yaitu, (a) name berisi nama, (b) private key sebagai masukan untuk mengunci gambar face person kunci mengunaka algortima AES 256 bit, (c) address untuk masukan alamat user, (d) nationa-id sebagai input nomor KTP, (e) birth info input tempat dan tanggal lahir, (f) gender untuk input jenis kelamin, dan (f) balance digunakan untuk input saldo user simapng di bank.

Pada proses enrolment gambar 7, bagian nomor (2) tedapat 2 proses yaitu (a) dengan button take a photo digunakan untuk mengambil poto wajah secara realtimeatau langsung dengan kamera belakang dan (b) dengan button from gallery digunakan untuk melakukan input gambar wajah dari komputer atau bukan dengan kamera belakang mobile secara langsung.

Pada proses enrolment gambar 7, bagian nomor (3) merupakan proses pengambilan poto wajah dengan kamera belakang secara real-time atau langsung.

Pada proses enrolment gambar 7, bagian nomor (4) merupakan hasil proses deteksi wajah pada gambar potoh yang di ambil.

Pada proses enrolment gambar 7, bagian nomor (5) merupakan data face person yang tersimpang di dabase face bio.

\section{b. Proses ujicoba Simpan Data user Cloud Server}

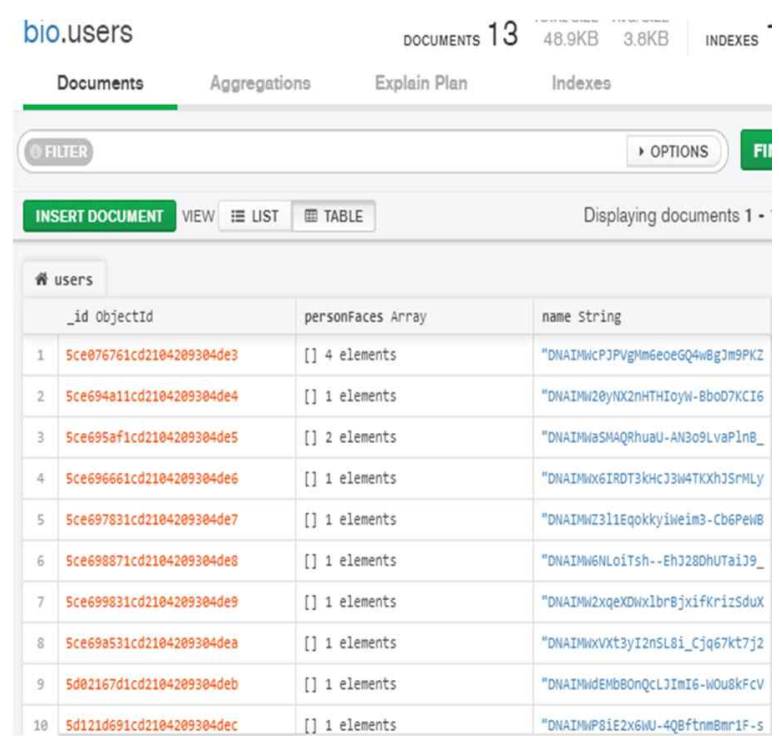

Gambar 8. Database Cloud Bio
Pada implementasi store database bio ke cloud server yang di bangun oleh peneliti dengan alamat jaringan server cloud, SLLpada gambar 4.3, database yang di bangun mengunakan mongoDB, database yang dibangun dengan nama bio dan tabel dengan nama users dengan memiliki kolom 12 yang terdiri dari, (1) id object bersih id face, (2) person-faces berisi jumlah potoh yang di di simpan di dabase, (3) nama berisi nama daripada user, (4) person-id id dari person, (5) private key berisi kunci algortima AES 256 bit untuk enkrispi face. (6) qurl merupakan url dari jaringan, (7) balance merupakan saldo user yang ada di bank, (8) gender berisi jenis kelamin dari user, (9) alamat sebagai alamat tempat tinggal dari user, (10) nid adalah id kTP dari user, (11) ttl merupakan sebangai tempat tanggal lahir, dan (12) V merupakan jumlah dari potoh face.

\section{c. Proses ujicoba create $Q R$ Code User}

Proses pembuatan $Q R$ Code sebagai kartu tanda pengenal bagi user. Ilustrasai QR Code user pada gambar 9.

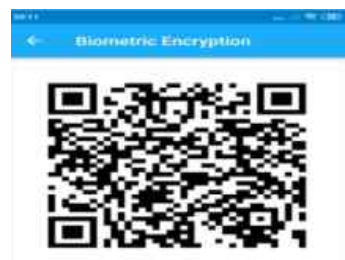

Gambar 9. Create QR

Pada proses pembuatan $Q R$ Code user pada gambar 9 dengan mengunakan gambar wajah user dan di enkripsi gambar wajah agar tidak mudah di baca code QR Code, QR Code sebagai kartu tanda pengenal user.

\section{Proses Ujicoba Menu Transaksi}

Pada proses menu transaksi ada 7 proses yaitu, (1) scan $Q R$ Code, (2) face detection, (3) face verification, (4) store transaction data, (5) input amount to pay (check balance), dan (6) transaction permission.

\section{a. Proses Menu ujicoba Scan QR Code}

Implementasi proses menu scan $Q R$ Code dan face verification merupakan proses autentikasi untuk 
melakukan proses transaksi. Dalam uji coba yang terdapat pada gambar 10 .

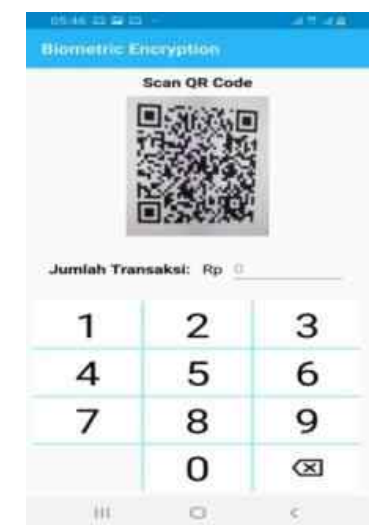

Gambar 10. Scan QR Code

Hasil ujicoba scan QR Code pada gamabr 10 tahap proses scan QR code ada 2 tahap yaitu, (1) masukan jumlah uang akan di bayar atas pembelian barang ke dalam teks input, (2) menempelkan kartu QR pada kamera belakang mobile samapai bentuk kartu QR Code semua tampil di segi empat pada menus scan QR Code. Dan proses scan akanberlanjut ke proses selanjutnya.

\section{b. Proses Ujcoba Face Detection Dan Face Verification}

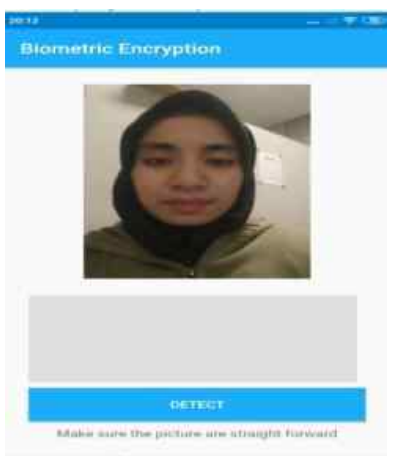

(1) Proses take a picture

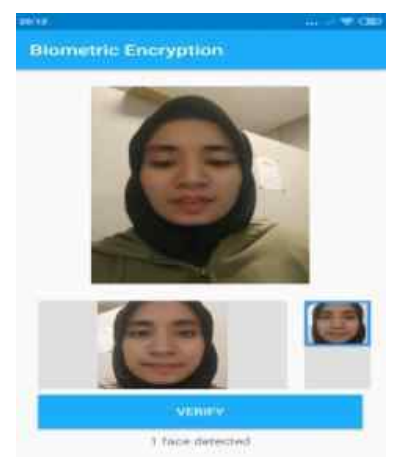

(2) Proses face detection
Gambar 11. Ujicoba Face Detection\&Verification

Hasil ujicoba proses face detection pada tabel 11 memiliki 2 tahap proses face detection, yaitu (1) mengambil potoh dengan kamera depan pas pada kotak segi empat pada mobile apps dan (2) tekan button detect untuk melakukan dekripsi face user dan melakukan matching face jika ada di database maka memberikan hasil detect seperti pada gmabar 4.5 bagian kanan dengan proses menu face detection.

\section{c. Proses ujicoba verifikasi}

Pada proses ini merupakan langkah untuk melakukan verifikasi face dan transaksi. Ujicoba pada ilustrasi gambar12.

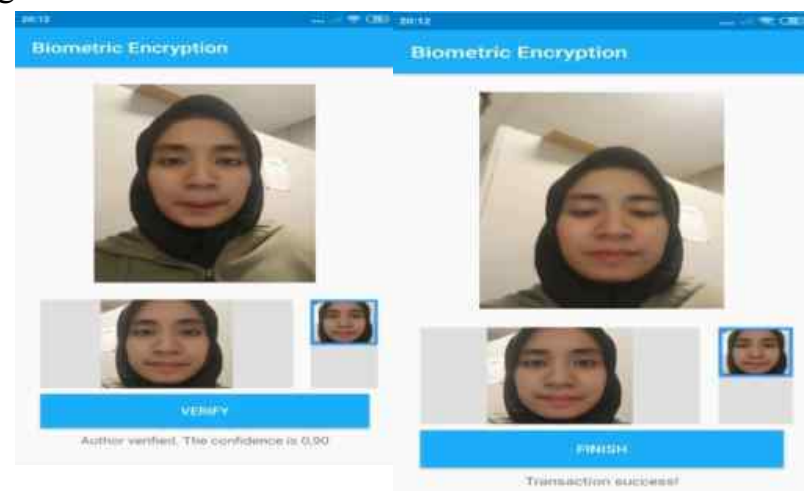

Gambar 12. Ujicoba Proses Verifikasi

Pada bagian proses face verification pada gambar 12 merupkan proses permission transaction, terdapat 2 tahap proses yaitu (1) setelah face sudah di deteksi dan melakukan matching antara face baru yang di ambil dengan kamera depan dengan face yang ada di dabase cloud server untuk melakukan matching maka autor mendapat konfidensial, (2) proses verifikasi untuk melakukan permission transaction, jika saldo balance dengan jumlah transaksi maka proses transaksi sukses dan sebaliknya.

\section{d. Ujicoba Storage Transaction Data}

Storage transaction data merupakan proses untuk menyimpan data transaksi market di database cloud server market. Ilustrasi Ujicoba penyimpanan data transaksi pada gambar 13 .

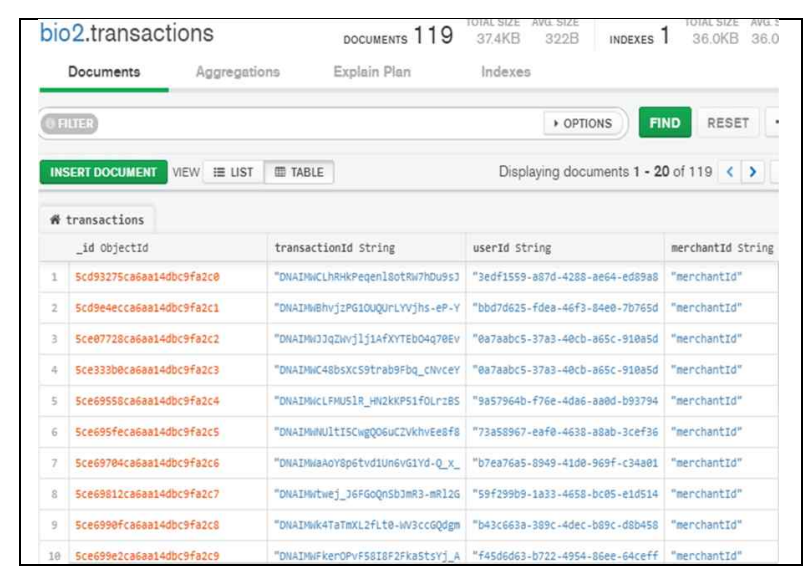

Gambar 13. Ujicoba Database Transaction Market 
Pada ujicoba store data transaction pada database market di cloud server dengan alamat jaringan server cloud SSL gambar 13 dengan nama database market, table transaction dan terdapat 7 kolom yang terdiri dari (1) id-object isi data face, (2) transaction-id berisi data trasanksi, (3) userid merupakan id dari user, (4) merchantid berisi data tempat transaksi, (5) balancebefore berisi saldo user sebelum dikurang dengan transaksi, (6) transaction amount berisi total transaksi, (7) balance after berisi sisah saldo di bank.

\section{e. Ujicoba Check Balance Transaction}

Pada Tahap Ini Melakukan Balance Check Transaksi, Ilustrasi Transaksi Pada Gambar 14.

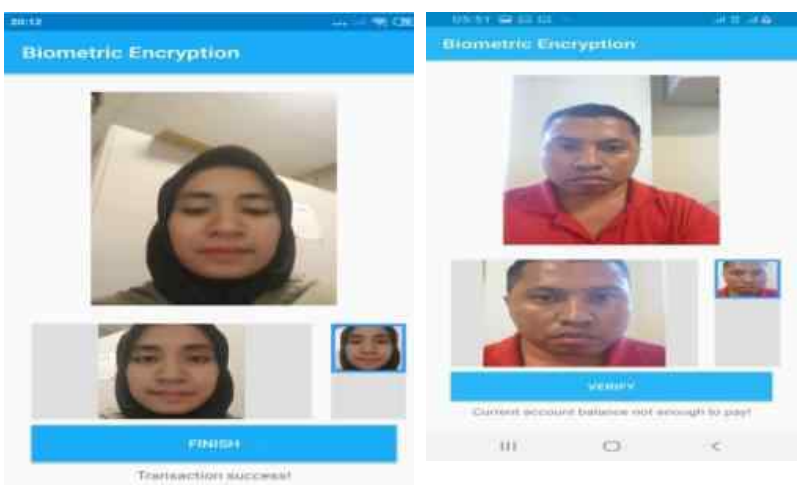

Gambar 14. Uji Coba Check Balance

Pada gambar 14 merupakan ujicoba dari balance transaction, dalam melakukan ujicoba terhadap balance transaciton mengunakan 2 kondisi yaitu, kondisi (1) transaction success jika melakukan check balance saldo bank dengan jumlah barang yang dibeli dimana saldo bank lebih besar atau sama dengan jumlah transaksi, kondisi (2) transaction fail atau current account not enough to pay, jika melakukan check balance saldo bank dengan jumlah barang yang dibeli dimana saldo bank lebih kecil daripada jumlah transaksi yang akan dibayar.

\section{f. Transaction permission}

Ada scenario ini melakukan face detectsdan face error. Ulustrasi pada gambar 15.
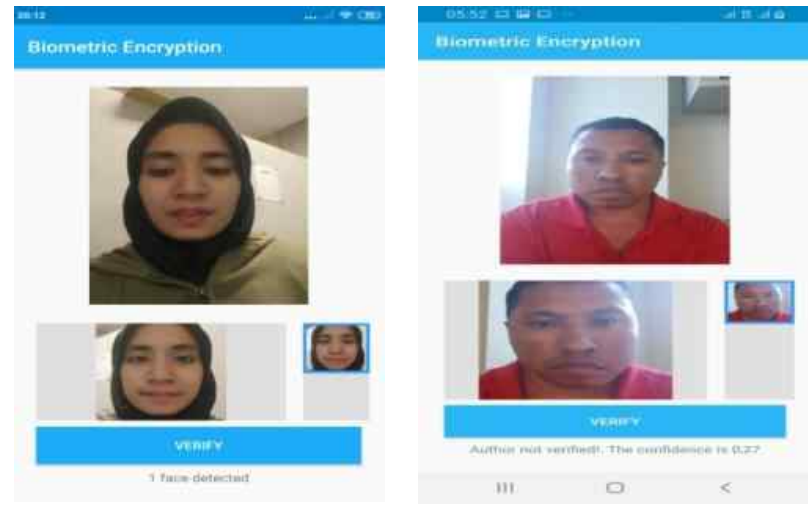

Gambar 15. Face Detection dan Face Error

Pada skenario pada gambar 15 merupakan hasil dari face detect dan face error. Pada gamabr face A ujicoba face detect karena face dan QR code sama orang dan face terdaftr pada database face di server cloud, sedangkan face error pada gamgar B sebaliknya.

\section{Ujicoba Akurasi Proses Face Recognize}

Pada hasil ujicoba permission acces transaction terhadap 10 orang untuk menganalisa tingkat akurasi kerbhasilan mobile apss melakukan transaction success dengan face recognize. Analisa ujicoba akurasi pada gambar 16.pada suatu aplikasi dikatakan memiliki akurasi yang tinggi jika dapat memberikan hasil output dari sebuah input dengan benar. Pada penelitian ini, tingkat akurasi diukur berdasarkan tingkat keberhasilan dalam melakukan kembali verifikasi wajah pada orang yang sama menghasilkan nilai true dan nilai falsa pada wajah yang berbeda.

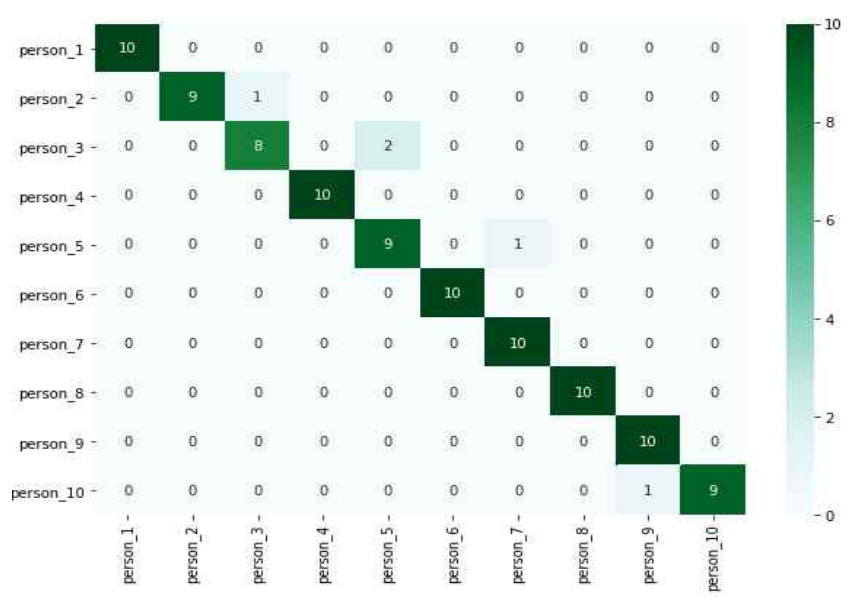

Gamabr 16. Grafik Akurasi Transction Permission 
Pada gambar 16 grafik data transaction permission terhadap 10 orang sampel ujicoba permission transction mengunakan beda face orang antar 1 samapi 2 orang berbeda success memberikan hasil bahwa fail transaction, sehingga hasil dari ujicoba memenuhi standar akurasi output sesuai dengan input. Dari hasil ujicoba dengan akurasi sebesar 95\% $\mathrm{t}$ permission transaction.

\section{E. Ujicoba Time Speed Proses Transaksi}

Proses ujicoba time speed untuk mengukur lama waktu dalam satu waktu melakukan proses autentikasi face verification.Ilustrasi ujicoba time speed pada gambar 17 .

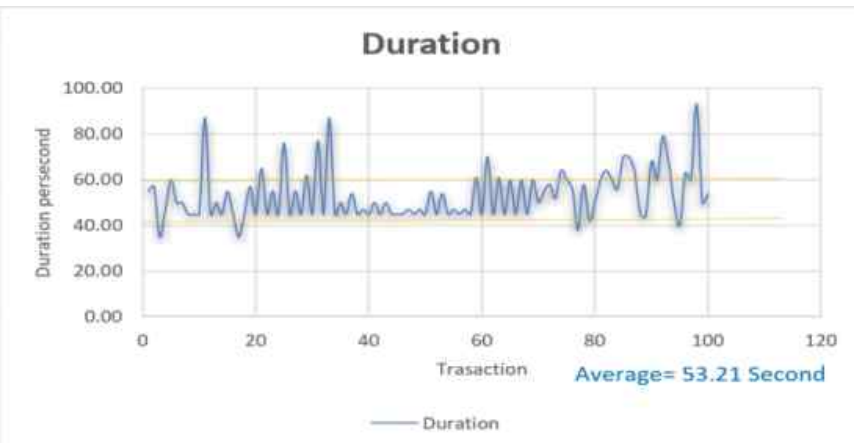

Gambar 17. Grafik Time Speed Transaction

Dari hasil analisis pada time speed pada gambar 17, menujukan bahwa waktu yang dibutuhkan untuk melakukan transaction permission hanya membutuhkan waktu rata-rata 53.21 second untuk melakukan sekali transaksi, dengan data transaksi sebanyak 100 kali.

\section{Kesimpulan}

Mobile Platform Biometric Cloud Authentication adalah mobile apps autentikasi dengan biometric untuk melakukan permission transaction. Permission transaction memgunakan beberapa data berupa seperti kartu $Q R$ Code dan Face recognize atau verification. Biometrik autentikasi adalah autentikasi dengan mengunakan salah satu bagian tubuh manusia seperti wajah, retina, sidik jari, suara, dan lainnya.

Konsep Mobile Platform Biometric Cloud Authentication yang diterapkan adalah metode algortima AES 256bit digunakan untuk enkripsi dan dekrispi biometrik face. Agar untuk mencega pemalsuan data biomerik face.

Permission transaction yang digunakan adalah kartu $Q R$ Code dan face authentication, data face disimpang di cloud server sehingga mudah melakuakn kontrol dan manajemen. Mobile apps authentication dibangun mengunakan sistem operasi android minimal API Level 22 lollipop.

Dari keseluruhan dari penelitian atas tesis ini disimpulkan bahwa :

1) Terdapat 2 proses utama dalam implentasi yaitu, registrasai dan transaksi.

2) Mobile transaction permission di implementasikan untuk transaksi merchant dan berjalan secara online access.

3) Authentication permission transaction mengunakan 2 kali autentikasi, yaitu (1) dengan $Q R$ Code (2) face verification.

4) Biometrik face authentication enkripsi dan dekrispi dengan algortima AES 256 bit.

aplikasi yang dibangun dengan mobile android dengan tingkat akurasi permission transaction 95\% dan time speed 53,21 second per transaksi. 


\section{Daftar Pustaka}

[1] Badan Pusat Statistik Indonesia, "Profil Kemiskinan di Indonesia September 2017," BPS (Badan Pusat Statistics), 2018, vol. 01, jakarta, pp. 1-12.

[2] I.M.Alsaadi,"Physiological Biometric Authentication Systems , Advantages, Disadvantages And Future Development: A Review,",2015,Int. J. Sci. Technol. Res., vol. 4, no. 12, pp. 285-289.

[3] B. Ammour, T. Bouden, and S. Amira-Biad, "Multimodal biometric identification system based on the face and iris," 2017, 5th Int. Conf. Electr. Eng. Boumerdes, ICEE-B 2017, vol. 2017-Janua, pp. 1-17.

[4] D. Chen, X. Cao, F. Wen, and J. Sun, "Blessing of dimensionality: High-dimensional feature and its efficient compression for face verification,",2013,Proc. IEEE Comput. Soc. Conf. Comput. Vis. Pattern Recognit., pp. 3025-3032.

[5] D. Chen, X. Cao, L. Wang, F. Wen, and J. Sun, "Eccv_2012_Bayesian.Dvi,",2012,no. 1, pp. 1-14.

[6] C. L. Tsai, C. J. Chen, and D. J. Zhuang, "Secure OTP and biometric verification scheme for mobile banking," Proc. - 2012 3rd FTRA Int. Conf. Mobile, Ubiquitous, Intell. Comput. Music 2012, pp. 138-141.

[7] A. Amran, S. M. Nasution, and F. Azmi, "Implementasi Algoritma Kriptografi pada Sistem Biometric Payment," Implementasi Algoritm. Kriptografi pada Sist. Biometric Paym., 2013,vol. 3, no. 1, pp. 1-10.

[8] S. Guan, R. E. De Grande, and A. Boukerche, "A novel energy efficient platform based model to enable mobile Cloud applications,",2016Proc. - IEEE Symp. Comput. Commun., vol. 2016-Augus, pp. 914-919.

[9] M. Azure, Face API Azure Doumentation.2017.

[10] X. Cao, Y. Wei, F. Wen, and J. Sun, "Face alignment by explicit shape regression,",2014Int. J. Comput. Vis., vol. 107, no. 2, pp. 177-190.

[11] W. Zhang, "Online Invoicing System Based on QR Code Recognition and Cloud Storage,",2018Proc. 2018 2nd IEEE Adv. Inf. Manag. Commun. Electron. Autom. Control Conf. IMCEC 2018, no. Imcec, pp. 2576-2579.

[12] P. Tresadern et al., "Mobile biometrics: Combined face and voice verification for a mobile platform," IEEE Pervasive Comput.,2013, vol. 12, no. 1, pp. 79-87.

[13] X. Sun and N. Ansari, "Green Cloudlet Network: A Sustainable Platform for Mobile Cloud Computing,",2017,IEEE Trans. Cloud Comput., vol. XX, no. XX, pp. 1-14.

[14] M. Stojmenovic, "Mobile cloud computing for biometric applications,",2012, Proc. 2012 15th Int. Conf. Network-Based Inf. Syst. NBIS 2012, pp. 654659.

[15] R. Stefan and S. Daniel, "Cryptography for Securty and Privacy in Cloud Computing,",2014, Artech House Computer Security Library.
[16] F. Omri, S. Foufou, R. Hamila, and M. Jarraya, "Cloudbased mobile system for biometrics authentication," 2013 13th Int. Conf. ITS Telecommun. ITST 2013, pp. 325-330, 2013. 